\title{
Exploring the Phenomenology of Whiteness in a Swedish Preschool Class
}

\author{
Eva Schwarz ${ }^{1} \cdot$ Beatriz Lindqvist ${ }^{2}$
}

Published online: 7 February 2018

(C) The Author(s) 2018. This article is an open access publication

\begin{abstract}
This article explores how constructions of identity, race and difference permeate and are challenged in a Swedish preschool class. The study is informed by theories of phenomenology and critical whiteness. Data are drawn from a larger ethnographic study conducted in an ethnically diverse preschool. The purpose of the study was to explore how preschool teachers manage and reflect upon the construction of children's social identity within the institution of a preschool. This report considers one incident relating to racial identity. It began with a child's representation, the boy named Stanley, in a self-portrait: 'I want to be white and blonde when I grow up... I want to be like Oscar, not a black boy'. Within this article we consider teachers' reflections on this incident, discussing how 'whiteness' is performed, constructed and interrogated by young children and adults in the preschool and uncovering a certain institutional 'colour blindness'. In this example 'race' announces itself and the children make it visible as an existing category in their everyday life. Children's drawings and narratives reveal much about the implicit understandings and norms that surround them, pointing to teachers' responsibilities for exploring the possibilities and limitations offered in preschool education to deal with these understandings.
\end{abstract}

Keywords Preschool - Sweden · Critical whiteness theory · Phenomenology · Reflexivity

Eva Schwarz

eva.schwarz@sh.se

Beatriz Lindqvist

beatriz.lindqvist@sh.se

1 Centre for Studies in Practical Knowledge, Södertörn University, Alfred Nobels allé 7,

14189 Huddinge, Stockholm, Sweden

2 Department for Ethnology, Södertörn University, Alfred Nobels allé 7,

14189 Huddinge, Stockholm, Sweden 
Resume Cet article explore la façon dont les constructions de l'identité, de la race et de la différence s'infiltrent et sont remises en question en classe maternelle en Suède. Les bases théoriques de cette étude sont la phénoménologie et l'approche critique de la «blancheur». Les données proviennent d'une étude ethnographique plus vaste menée dans une école maternelle où la diversité ethnique existe. Le but de l'étude est d'explorer comment les enseignants de maternelle gèrent et réfléchissent sur la construction de l'identité sociale des enfants à l'intérieur de l'institution de l'école maternelle. Ce rapport examine un incident lié à l'identité raciale. Tout a commencé avec la représentation de lui-même d'un garçon, Stanley, dans un autoportrait: «Je veux être blanc et blond quand je serai grand... Je veux être comme Oscar, pas un enfant noir». Dans cet article, nous examinons la réflexion des enseignants sur cet incident, en discutant de la façon dont la «blancheur» est représentée, construite et mise en cause par les jeunes enfants et les adultes dans l'école maternelle, en révélant également un certain aveuglement institutionnel relatif à la couleur de la peau. Dans cet exemple, la «race» se proclame d'elle-même, et les enfants la rendent visible en tant que catégorie existant dans leur vie quotidienne. Les dessins et les propos des enfants révèlent un grand nombre de conceptions et de normes implicites qui les entourent, renvoyant ainsi aux responsabilités des enseignants d'explorer les possibilités et les limites qu'offre l'éducation préscolaire pour agir face à ces conceptions.

Resumen Este artículo explora cómo los profesores y niños, en un pre-escolar sueco de diversidad étnica, negocian construcciones raza y diferencia, que supuestamente no existen en el ámbito pre-escolar, donde el discurso de la "ceguera de la raza" es predominante. El estudio está informado por las teorías de la fenomenología y la teoría crítica de raza. Los datos provienen de una investigación etnográfica más amplia sobre la construcción de la identidad social de los niños dentro de la institución de un preescolar. Como ejemplo, tomaremos un incidente relacionado con un niño de origen africano llamado Stanley que, dibujando un autorretrato, rechaza el color de su piel. En este artículo consideramos las reflexiones de los maestros sobre este incidente, discutiendo cómo la "blanquitud" es articulada en actividades cotidianas que la tornan inperceptible, y cómo el dibujo y las palabras de un niño de color producen una dislocación que revela la existencia de una supremacía blanca en el discurso antirracista de educación. En este ejemplo, la "raza" se anuncia y los niños la hacen visible como una categoría existente en su vida cotidiana. Los dibujos y narraciones de los niños revelan mucho acerca de las normas implícitas que los rodean, señalando las responsabilidades de los maestros para interrogar las limitaciones ofrecidas en la educación preescolar para tratar con estos conceptos. 


\section{Introduction}

How do young children understand and experience race, racism and diversity in early years contexts in Sweden? What is the role of the institutional setting and preschool teachers' professional self-understanding with regard to this question? This study addresses these issues through analysis of an incident in a preschool classroom. The data were drawn from a larger ethnographic study focused on the construction of children's social identity in early childhood education. During the course of the fieldwork both children and staff revealed more or less implicit understandings of 'whiteness' that appeared to shape subjectivities. This article uses the concept of 'whiteness' as a framework for our discussion about race and identity in preschool. The study is informed by phenomenology (Husserl 1971; MerleauPonty 2010) and critical whiteness theories (Ahmed 2006, 2007; Hübinette et al. 2012). The aim of this article is to explore how young children and staff understand and experience race, racism and diversity in an early years context.

Swedish preschool is an explicitly educational institution for children between the ages of one and five, in which 83 percentage of Swedish children are enrolled. The largest group is 4 and 5 year olds, the age group which our article will focus on. Of this age group, 94 percentage of children attend preschool. However, during the past decade the proportion of children enrolled has increased in all age groups (Skolverket 2016). Since 1998 preschool in Sweden has been recognised in its own right, with a national curriculum, which was revised in 2010 and 2016. The curriculum sets out central principles and values to undergird the practices of early childhood education, such as: '[t]he inviolability of human life, individual freedom and integrity, the equal value of all people, equality between the genders, as well as solidarity with the weak and vulnerable' (Skolverket 2010, p. 3). While gender equality is covered there is no mention of 'race'. Later on in the curriculum it is stated that preschool will strive to ensure that each child develops 'an understanding that all persons have equal value independent of social background and regardless of gender, ethnic affiliation, religion or other belief, sexual orientation or functional impairment' (Skolverket 2010, p. 8, our emphasis). In one chapter, the value of 'cultural diversity' is discussed (Skolverket 2010, p. 8, our emphasis), which, it is said, will provide children with the opportunity to build up respect and consideration for each individual irrespective of background (Skolverket 2010, p. 8). Another important principle, besides equality, that characterises both the curriculum but also Swedish discourse on early childhood education, is the idea of the child as competent individual, fully capable of exploring the world and reflecting upon it. The pedagogue is defined as someone who should take the perspective of the individual child seriously and follow the child in his or her explorations (Åberg and Lenz Taguchi 2005). The principles of equality and 'individuality' confront preschool staff with dilemmas on different levels (Schwarz 2016): How to treat everybody alike, and simultaneously focus on the individual child; and how to deal with the obvious inequalities between the children, in terms of skills, social background and future prospects? 
Despite increasing refugee migration during recent decades, there are only a few studies that investigate questions of race or racism in early childhood education (Andersen 2015). Yet extensive research has been done on ethnic or cultural 'diversity' and language, revealing that diversity is often either found to be problematic or neglected in the planning, provision or evaluation of services (Lanå 2015; León Rosales 2010; Lunneblad 2013; Runfors 2010). Ethnic diversity is discussed either in terms of a deficit that has to be compensated for in order to establish 'equality' or as an 'enrichment' adding 'exotic influences' from the outside, following an ideal of 'multiculturalism'. In both cases, it has been argued, there is a risk of 'othering' some children by either noticing or ignoring visual difference (Johansson 2008; Johansson and Hammarén 2010). The colour blind strategy is counterproductive as it tends to hide the mechanisms that reproduce social inequality. Colour blind teachers are silent about racism, while black children are trying to make sense of their experiences of how discrimination influences their lives (Lundberg 2015; Motsieloa 2003). International research has found that employing ethnically diverse staff members in welfare services is effective at including and meeting the needs of ethnic minority families (Lloyd and Rafferty 2006; Ward 2013). On the other hand, there are also reports that welfare services targeting 'ethnic minorities' tend to essentialise groups and homogenise their needs (Gruber 2007; Lewis 2000; Öhlander 2005).

While 'critical whiteness' has been used as a framework to understand institutional discourses and practices in a number of educational settings (Gruber 2007; Lanå 2015; Lundberg 2015) in this paper, we will argue that the teachers' standpoint of 'not seeing the colour but the individual' is harmful as it ignores the experiences of minority children. Further we will demonstrate that teachers' interrogation of norms of whiteness may open up the potential for an interruption of the taken-for-granted that recognises the ubiquity of race in their practice and indicates the need for new inclusive teaching strategies.

\section{Theoretical Framework}

In this article, we employ a phenomenological approach to experience, defining it as always already situated in an intersubjective, bodily, culturally constituted world. 'Experience' indicates not just certain unknown internal mental states but the very relation in, and through, which the world appears as meaningful, to both adults and children (Merleau-Ponty 2010, p. 247). Still, they are always someone's experiences and take place in the here and now of a certain situation. In this sense, they are never fully 'objectifiable' but always open to interpretations and re-understandings, even to the person in the situation. Relating to my own perspectival experiences, to questions of who I am and who I might become in the future, involves relating to my own history of experiences, habits and desires, to try to capture the meanings and forms. This holds true for the experiences of others as well. As researchers, we are confronted not only with the blind spots of our perspective but also with our own experiential histories and habitualisation of views (cf. Schwarz 2011). 
This is what forms our 'natural attitude' towards the world and the structures of our everyday life which is of interest to phenomenologists. Yet, these structures are, as Husserl (1971) points out, not visible in the natural attitude, as they are functioning but they do not 'appear'. In order to investigate those structures that are always already 'in play', we have to step back from the natural attitude and take a broader perspective towards ourselves and our worldly encounters (Husserl 1971). This can both happen voluntarily, for example, when starting to reflect theoretically, or involuntarily, such as in situations where the self-evident loses its evidence, when we are confronted with a gap, when we start to doubt.

Sara Ahmed has developed the concept of 'whiteness' by referring to the phenomenological description of experience as based on certain habitual ways in which subjects orient themselves in the world. For her 'whiteness' is not to be reduced to the colour of one's skin. In fact, it is about certain ways, certain styles of world-constitution, which someone inhabits in the course of their experiential life. The discourse of 'whiteness' expresses itself along lines of belonging, where people move through the world directing themselves towards or away from objects and others: When we talk about objects we include not just physical objects, but also styles, capacities, aspirations, techniques and habits. 'Race' becomes a question of what is or is not within reach, what is available to perceive and to 'do things with.' (Ahmed 2007, p. 154) In Queer Phenomenology Ahmed (2006) also uses the term 'orientation' in describing the concept of 'whiteness': "If orientation is about making the strange familiar through the extension of our bodies into space, then disorientations occurs when this extension fails. Or we could say that some spaces extend certain bodies and simply do not leave room for others" (Ahmed 2006, p. 11). Whiteness is about familiarity, about being at home in one's life. The problem with 'whiteness' is that those who are included in it are seldom aware of it. Those who are 'at home', those who can extend their bodies in space, seldom ask what it means to be at home, to be oriented. According to Ahmed bodies take shape as they move, directing themselves towards or away objects and others (Ahmed 2006 , p. 2). Not being included in the norm of whiteness means, according to Ahmed, to be constantly reminded of one's bodily being, the necessary transparency of the body, as a given condition to 'feel[ing] at home in your body', when it is constantly feeling out of place (Ahmed 2006, p. 2).

In the case of the boy named Stanley, whose experiences are discussed in this text, he expresses awareness that his black body does not fit the narrow range of physiognomies considered as 'normal' spatially, discursively and phenomenologically in Swedish society (Habel 2012). The embodied experience of racialisation and whiteness among children in Swedish preschool contexts has not been explored within previous research. The contribution of this research is to advance understanding of the function of whiteness in preschools and forces a recognition of associated issues for professional practice. 


\section{Methods}

This article is based on data from an ethnographic study that was carried out in a multiethnic preschool in Sweden in 2014 and 2015. Participant observation was carried out during 1 week of every month of the year. Initially the focus was not specifically on questions of 'racialisation' and 'whiteness'. The specific questions were more broadly focused on how preschool teachers deal with and reflect upon the constitution of children's social identity in, and via, early childhood education. At the time of our field study there were about 100 children between the ages of 1-5 years at the preschool. The methods used were participant observation in various situations and focus group interviews with teachers. Photo elicitation was used in conversations with children and staff (Einarsdottír 2005; Jorgenson and Sullivan 2010; Thomson and Hall 2008). The data were handled confidentially and all names used in this research report are pseudonyms.

In this article, we are focusing on one subgroup of five children who were 5 years old at the time and their three teachers. For many of the children, it is their last year at preschool. The teachers are very thorough in preparing the children for their move to different schools. They know that not all of the children will attend schools with good reputations and that not all of the children have parents who will be able to support them in their educational processes. The initial assumption during the observations was that both children and staff in this preschool have overcome 'the racialization in society' (Hübinette et al. 2012). However, during the course of the fieldwork we changed focus since both children and staff revealed that a more or less implicit understanding of 'whiteness' shapes subjectivities and much of what is embedded in daily routines. In the following we are focusing on certain situations, which were significant to us but also to the subjects involved, situations that changed not only the staff's perspective on their work but also our perspective on our research.

\section{Findings}

At preschool the embodied experiences of the children and pedagogues find their form not only in words, but also in gestures, interactions, and creative work. The children in this study are the creators of photographs and drawings, using paper, pencils, crayons, and tablets in their everyday practice at preschool. We consider these drawings as a way to get closer to their understanding of the world, to appreciate their views, to reconstruct the ways in which they constitute the world (Cox 2005; Harper 2002; Merleau-Ponty 2010). We paid close attention to the narratives that developed around the drawings since they, beyond being merely representation, are seen as parts of a process of the exploration and negotiation of meaning. 


\section{Drawing a Self-Portrait}

The children at this preschool engage with drawing, sculpturing and storytelling on a daily basis. As the children are observing and describing the parts of the human body, the teacher invites each child to take a picture of herself or himself with a tablet computer. The teacher prints the photos and distributes them, so that each of the six children in the atelier has their own portrait on the table and can start drawing. After sketching a head, the children add colour to the eyes, mouth and hair. Meanwhile a discussion starts between two girls, Mona and Nelly, in Arabic. Finally, they comment on Stanley's face drawing in Swedish, so that he will understand. 'What are you doing, silly? That's not you!' exclaims Mona, laughing. 'Who is that?' Nelly asks and looks for the teacher's attention, apparently wanting her to explain to Stanley that what he did is wrong since he is black. As the teacher comes closer Mona complains: 'Stanley refuses to do it right! Look at his drawing, that's not him!' 'Look at my picture, it looks like me!' says Nelly with pride as she finishes colouring the brown eyes on her paper.

Stanley doesn't show any irritation at all as he waits for the teacher to comment on his drawing. She looks at the pale figure on the paper and asks Stanley with a calm and warm voice: 'Tell me about your drawing, how you see the portrait'. 'Is that you?" teases Nelly "do you really look like that?' As they make fun of Stanley and look for support in our faces, Stanley gets triggered and explains:

Stanley: That is me when I grow up and become adult!

Teacher: You mean, in the future, do you mean that you'll going to look like that then?

Stanley: I want to be white and blond when I grow up!

Teacher: Why is that? You are a handsome boy today!

Stanley: I want to be like Oscar, not a black boy!

(Fieldnotes 02-03-2015)

In this drawing session, as is usual when the children engage in aesthetic learning, they animatedly discuss their work and views on what they are doing and thereby disclose, as we see it, their understanding of their social world and of their place in it. In previous sessions their drawings and conversations have been related to ideas of being someone or something else, such as what it would be like to be a princess or a certain animal. This time the reactions show that something is different. Mona and Nelly are upset that Stanley is not fulfilling the task of drawing a 'correct' selfportrait, thereby underscoring that they are aware of the norms of representation. A portrait of oneself shall mirror one's looks in reality: 'Look at my picture it looks like me.' Looking at the teacher, Mona expects her (and the researcher, as part of the adult order), to confirm this idea. The idea that every child's work of art is equally valuable as it is an expression of a certain perspective on the world is challenged by the girls' idea of a portrait as a representation of who you are and how you look. The girls' mocking of Stanley, as seen against a social justice agenda, offers an insight into the many ways that children relate to the sometimes contradictory social order of the preschool (cf. Dolk 2013). 
The teacher is reacting on another level: She objects to Stanley's daydream of a white future by affirming the positive value in his (black) looks: 'Why is that? You are a handsome boy today!' However, Stanley insists on his wish of becoming white like his friend. The preschool teacher approaches Stanley's drawing (seemingly) neutrally and asks him about his thoughts, thus emerging as a 'co-researcher' who follows the child's ideas and perspective (Åberg and Lenz Taguchi 2005). He extends his wish with a negative statement: 'I want to be like Oscar, not a black boy'. He expresses his wish not to be a certain kind of boy, 'a black boy', and to be like someone else from his group. To be 'a black boy' is not something positive for him. He wants to become 'white like Oscar'. He seems to be very determined in this wish.

The teacher and Stanley use different phrasings in describing Stanley's future portrait: The teacher asks whether he will 'look like that' in the future. For her it seems to be a question of 'looks', whereas Stanley answers that he wants to 'be white'. Referring to him being 'handsome' emphasises her more externalised focus, a question of being handsome or not. Yet, for him it might be a question at a deeper, more existential level, a question of 'being'. Looking handsome or not does not seem to be Stanley's main concern as the conversation changes its focus to time: Stanley is no longer speaking about the future. He wants to 'be like Oscar', a child who in his eyes is 'not a black boy'.

The example of Stanley wanting to be white exposes what is otherwise omitted and passes unseen: inhabiting the world in a white body implies possibilities which are beyond reach for black bodies. In this sense it is possible to interpret it as a black child's insight into the structural advantage that privileges whiteness as the human norm (Dyer 1997; Frankenberg 1993).

\section{The Teachers' Weekly Reflection Meeting}

As happens every Friday before lunch, while the children are engaged in outdoor activities with teachers from another group, the three teachers responsible for the group of children that includes Mona, Nelly and Stanley, gathers for their weekly reflection. This particular day the episode with Stanley's portrait is at the core of their discussion:

Malin: It's not unusual, regarding the existence of racial oppression.

Katrin: But come on, we are in Sweden, you cannot talk about race, it's more related to the fact that he feels a bit different coming from Liberia. He is the only one from that country...

Stina: I'm more inclined to think a bit like Malin, he feels uneasy with the colour of his skin because he is black. Probably he's met prejudices out there. But it really hurts to hear that he doesn't like himself. It hurts that he drew his mum white as well... She is such a great person!

Katrin: Whatever, this cannot go on unnoticed. We must do something...

As in many other situations, Malin, the arts teacher with long experience of working in ethnically diverse schools in other countries, has many suggestions for the group: 
We should give the children a broader range of possibilities to identify with and to describe, represent and perform in visual arts and drama. What do you think about that?

(Fieldnotes 20-03-2015)

Malin is calling for a change, an intervention directed at enriching the availability of diverse representations of children, which would allow the preschoolers to acknowledge human physical diversity as normality. The teachers continue discussing viable pedagogical strategies to address the issue, and go back to the human representations that the children have worked with prior to this incident. Having the episode with Stanley in mind, the teachers' gaze on the paintings is now more conscientiously focused on detecting the presence of 'whiteness' that goes on unnoticed as the 'absence of colour'. They discuss how most girls have been painting princesses in spontaneous activities. Regardless of the child's individual complexion the representation of a princess consists of a young white girl with blond hair and blue eyes.

This discussion among the teachers shows that their habitual ways of seeing, or 'orientations', are interrupted. They are confronted with their understandings and blindness with respect to an important dimension of the children's situatedness and their own role in it. The question of 'whiteness' is discussed as something which they are not only part of, but are constituting through their actions, and as something society is also constituting and maintaining.

\section{Institutionalised Whiteness in Early Childhood Education in Sweden}

For preschool teachers in Sweden racialised power is not acknowledged as a present dimension of their everyday practices (Andersen 2015), and they instead talk about culture, religion and ethnicity impacting on contacts with parents and children ('But come on, we are in Sweden, you cannot talk about race'). However, as our study shows, 'race' announces itself when the children make it visible as an existing category in both society and their everyday life. This example is a reminder that racialisation flickers at the margins of the Swedish vision of equality for all, as reflected in the curriculum.

In another situation, Stanley reports that his face is blurred in pictures and warns the researcher as she intends to take a picture of him and other boys playing: 'You will not be able to see that it's me in the picture. You do not see that it's me. Melody's face looks like a stain as well!' (laughs) Looking at a class portrait the teachers notice that the black children's faces are difficult to individualise, probably due to exposure or lighting that adjusts to the complexions of the fair skinned children (Fieldnotes 14-04-2015).

Richard Dyer has tracked the ways in which whiteness as an invisible norm informs the technologies of photography and film. He argues that 'photographic media and [...] movie lighting assume, privilege and construct whiteness' (Dyer 1997, p. 89). According to Dyer, the technologies 'were developed taking the white face as a touchstone' (1997, p. 90), which explains why, for instance, 'the black pupils' faces look like blobs or the white pupils have theirs bleached out' when they 
are photographed together in school photos (1997, p. 89). Keeping Dyer's words in mind it is possible to interpret Stanley's warning, 'you will not be able to see that it's me', as evidence of the misrecognition that black Swedish children constantly confront. The picture acts as a materialisation of their feelings of discomfort and disorientation, because neither Stanley's nor Melody's bodies fit the norm in spaces which presuppose that a child is white and blond.

The following discussion of the teachers is about light exposure when taking good pictures of black children, and the white paper used for drawing that is too white to be covered with colour from felt tip marker pens. Until now the teachers had followed the logic of colour blindness predominant in Swedish education. 'Whiteness', writes Ahmed, 'is only invisible for those who inhabit it, or those who get so used to its inhabitance that they learn not to see it even when they are not in it' (Ahmed 2007, p. 157). What the teachers have learned to see is not the colour of Stanley's skin, but 'whiteness' as a form of seeing certain things and not seeing others. It is not only their own way of seeing they unfold but the institutional, habitual repetition of doing things in a certain way, of asking kids to draw a portrait, choosing certain books and images, seemingly innocent questions and activities, all posed from the perspective of 'whiteness'.

'Colour blindness' fails because it neither enables discussions about the influence of racialised power relations privileging whiteness at the cost of minority children, nor enables black children to resist oppressive structures in society. A critical examination of the images, narratives, books and activities provided at preschool appears crucial in order to facilitate identification, a necessary condition to 'feel[ing] at home in your body' and in the world, which is constantly a feeling of being out of place for some children.

However, as Chapman (2013, p. 614) explains, well-intentioned teachers tend to neglect the impact of racialisation: 'The discourse of colour blindness allows school adults to disregard the racial identities of students by solely viewing them as individuals who are divorced from the social, economic, and cultural factors that shape their past and present experiences' (Chapman 2013, p. 614). Accordingly, Stanley's experience with the hegemony of whiteness can also be understood through the distinct contexts of segregated housing, high rates of parental unemployment and economic vulnerability of visible minorities in the city where our research took place. Swedish multiethnic preschools are still predominately white institutions despite the ethnic diversity of the children and staff. As previous research demonstrates, in Swedish educational discourse issues of equity and equality are framed through policies and practices that attempt to treat all children the same (Lunneblad 2013; Runfors 2013). Social injustice is framed as a problem of cultural difference to be solved, with the goal of equality envisaged as being possible to reach through seeing and treating everyone as the same, and thus reducing problematic difference.

Teachers in Swedish multiethnic preschools-who in many cases are the only white adults that minority children encounter during the day-uphold an image of colour blind equity by stating that 'here we are all the same', invoking zero tolerance against offensive speech and approaching all the children with attentiveness, thoughtfulness and consideration. On the other hand, Stanley's teachers 
experience something different while reflecting upon this black preschooler drawing a white self-portrait. The drawing alters the teachers' common understandings as it echoes experiences moulded by living in a segregated city that the principle of colour blindness fails to explain. After acknowledging that the racialisation of society has both an emotional and an economic impact on the children the teachers agreed to collectively examine their approach to particular situations.

During the following reflection meetings, the teachers listened carefully to each other's accounts of their experiences during recent weeks. The participants shared their difficulties, and this time Malin, who is usually prone to offering suggestions that have worked for her before, asks: 'I think we lack the ability of understanding this in its entire depth...' By pointing this out Malin brings up questions about how the teachers interpret children's voices, actions and emotions through the lens of whiteness with which their ethnic Swedish upbringing and social position provide them. Malin again:

'We understand Stanley's case and what we believe is appropriate for him, but we start out from ourselves as if it were everyone's experience. Perhaps it is why we don't meet with Stanley where he actually is.' (Fieldnotes 17-042015)

The incidents with Stanley and Melody raise new considerations in the teacher's educational practice to reflect upon. According to Swedish preschool policy, experiential learning is a process in which all children are to be treated in respectful and engaging ways, and all children shall receive the same opportunities to reach their potential. Teachers have learned the strategies of colour blindness through both the formal curriculum and their informal mentorship over years working in preschools: 'På förskolan är alla barnen lika' ('all the children are the same at preschool'). Here, a discussion of possible meanings of 'equality' and 'difference' is needed. Meanwhile, as the teachers' reflections evolved they embraced a more conscious view of the disparities related to race and class in today's Swedish society, but still the group expressed a sense of disorientation, as Stanley's drawing materialised an overlooked reality in their preschool. A black child expressing a wish to grow up to be a white adult shows that minority preschoolers may experience existing in a black body as a 'problem', a disorientation. This can be seen as evidence that 'bodies stand out when they are out of place' (Ahmed 2006, p. 135-136), which reconfirms the whiteness of the (preschool) space.

Orientations depend on taking points of view as given, they 'shape not only how we inhabit space, but how we apprehend this world of shared inhabitance, as well as "who" or "what" we direct our energy and attention toward' (Ahmed 2006, p. 3). Orientations are thus the lenses that allow some things to come into focus at the expense of others, making some things easy to do and others nearly impossible. Orientations allow us and our bodies to 'fee[l] at home' and 'fin[d] our way' (Ahmed 2006, p. 9). As Ahmed states, 'whiteness becomes a social and bodily orientation given that some bodies will be more at home in a world that is orientated around whiteness' (2006, p. 138). Those with white bodies carry their given privileges in what McIntosh (1989) calls the 'invisible knapsack', which enables them to smoothly 'be at home' in the world. The world also shapes our bodies, 
evidently supporting bodily comportments, behaviours, and aesthetics that follow the 'program' of whiteness. 'If the world is made white,' Ahmed argues, 'then the body at home is one that can inhabit whiteness' (2006, p. 111). Accordingly, the discomfort of non-white bodies 'reconfirms the whiteness of the space' (Ahmed 2006, p. 135-136). Bodies that cannot or do not follow the norms of whiteness lead to feelings of discomfort, producing disorientation and disruption. As we see in the case of the black boy portraying himself as a white man in the future, the discomfort created by his unexpected visualisation of the unspoken norm results in the teachers' disorientation. Stanley's drawing might show that he is aware of lacking a compass to navigate the white-oriented world successfully and safely.

\section{Conclusions}

This study suggests that prevalent ideals of colour blindness in increasingly diverse Swedish preschools tend to reproduce whiteness as a norm despite the good intentions of the teachers. However, normative whiteness functions as a symbolic limit experienced by black children in their everyday realities. The example of the black boy Stanley portraying himself as a white blond boy in a drawing is interpreted as a representation of his insights into the limitations of access to a system of privileges that are granted to white boys like his friend Oscar but not to black boys like him. While racial identities are not acknowledged in the preschool context the pale figure in the drawing exposes what is supposed to be a matter that does not matter. Speaking in agreement with Ahmed (2007), we interpret the teachers' reactions to Stanley's words and drawing as 'queer practices' unveiling norms that tend not to be questioned, such as the desirability of becoming 'white' in order to be at home in Swedish society. As in the case of queerness discussed by Ahmed (2006), the uneasy display of whiteness disrupts relations of proximity by not following the accepted paths. The blurred images of Stanley and Melody in the class photo does not fit with the norms that they encounter in their daily lives and this makes them feel uncomfortable or disorientated. The unexpected naming of whiteness as race challenges the taken-for-granted assumption that race is irrelevant in preschool. Specifically, this article advances an understanding of the function of whiteness as a configuration of meanings and actual practices, through positioning white children and staff as an unproblematic norm and those marked as non-white as a category ignored through marginalising practices. However, the study shows that reflective preschool teachers can disrupt the unintended reproduction of whiteness as the norm. Abandoning taken-for-granted assumptions and practices engenders uncertainty as it forces a recognition of professional shortcomings. On the other hand, testing out new strategies to cope with new situations demonstrates that it possible, if not probable, to create learning spaces that contest the material realities of racial inequality in the larger society. Contesting the hegemony of whiteness, that in seemingly safe everyday activities reproduces itself as an invisible but still active power relation, does not have a quick fix that the teachers can easily apply. Instead it involves long-term critical self-reflection on taken-for-granted privileges, combined 
with empathy, which can be understood as a professional tool of the teaching profession.

Acknowledgements This study is part of the research project "Being and Becoming. "A phenomenological perspective on formative structures of preschool education in Sweden and Germany" funded by Östersjöstiftelsen (Foundation for Baltic and East European Studies).

Open Access This article is distributed under the terms of the Creative Commons Attribution 4.0 International License (http://creativecommons.org/licenses/by/4.0/), which permits unrestricted use, distribution, and reproduction in any medium, provided you give appropriate credit to the original author(s) and the source, provide a link to the Creative Commons license, and indicate if changes were made.

\section{References}

Åberg, A., \& Lenz Taguchi, H. (2005). Lyssnandets pedagogik: Etik och demokrati i pedagogiskt arbete [Listening pedagogy. Ethics and democracy in education]. Stockholm: Liber.

Ahmed, S. (2006). Queer phenomenology: Orientations, objects, others. Durham, NC: Duke University Press.

Ahmed, S. (2007). A phenomenology of whiteness. Feminist Theory, 8(2), 149-168.

Andersen, C. (2015). Mot en mindre profesjonalitet: “Rase”, tidig barndom og Deleuzeoguattariske blivelser [Towards a minor professionality: "Race", early childhood and Deleuzian becomings]. Diss. Stockholm: Stockholms universitet.

Chapman, T. K. (2013). "You can't erase race!" Using CRT to explain the presence of race and racism in majority white suburban schools. Discourse: Studies in the Cultural Politics of Education, 34(4), 611-627.

Cox, S. (2005). Intention and meaning in young children's drawing. International Journal of Art and Design Education, 24(2), 115-125.

Dolk, K. (2013). Bångstyriga barn: makt, normer och delaktighet i förskolan [Stubborn kids: Power, norms and participation at preschool]. Diss. Stockholm: Stockholms universitet.

Dyer, R. (1997). White: Essays on race and culture. London: Routledge.

Einarsdottír, J. (2005). Playschool in pictures: Children's photographs as a research method. Early Child Development and Care, 75(6), 523-541.

Frankenberg, R. (1993). White women, race matters: The social construction of whiteness. Minneapolis: University of Minnesota Press.

Gruber, S. (2007). Skolan gör skillnad: etnicitet och institutionell praktisk [School makes a difference: Ethnicity and institutional practice]. Diss. Linköping: Linköpings universitet.

Habel, Y. (2012). Challenging Swedish exceptionalism? Teaching while black. In K. Freeman \& E. Johnson (Eds.), Education in the Black Diaspora: Perspectives, challenges and prospects (pp. 99-122). London: Routledge.

Harper, D. (2002). Talking about pictures: A case for photo elicitation. Visual Studies, 17(1), 13-26.

Hübinette, T., Hörnfeldt, H., Farahani, F., \& León Rosales, R. (2012). Om ras och vithet i det samtida Sverige [On race and whiteness in contemporary Sweden]. Tumba: Mångkulturellt Centrum.

Husserl, E. (1971). Ideen zur einer reinen phänomenologie und phänomenologischen Philosophie [Ideas pertaining to a pure Phenomenology and phenomenological philosophy]. The Hague: Nijhoff.

Johansson, R. (2008). Skapandet av svenskglesa bostadsområden [Construction of housing areas sparsely populated by Swedes]. In L. Magnusson Turner \& E. Andersson (Eds.), Den delade staden (pp. 119-160). Umeå: Boréa.

Johansson, T., \& Hammarén, N. (2010). Konsten att välja rätt spårvagn: En studie av segregation, skolval och unga människors studieplaner [The art of choosing the right tram-A study of urban segregation, choice of school, and young people's life plans]. Sociologisk Forskning, 47(1), 51-71. 
Jorgenson, J., \& Sullivan, T. (2010). Accessing children's perspectives through participatory photo interviews. Forum Qualitative Sozialforschung/Forum: Qualitative Social Research, 11(1), Art. 8, Retrieved from http://nbnresolving.de/urn:nbn:de:0114-fqs100189.

Lanå, K. (2015). Makt, kön och diskurser: En etnografisk studie om elevers aktörsskap och positioneringar $i$ undervisningen [Power, gender and discourse: An ethnographic study of students agency and positioning]. Diss. Göteborg: Göteborgs universitet.

León Rosales, R. (2010). Vid framtidens hitersta gräns: Om maskulina elevpositioner $i$ en multietnisk skola [At the outer limits of the future. On masculine student positions in a multiethnic school]. Diss. Stockholm: Stockholms universitet.

Lewis, G. (2000). 'Race', gender, social welfare: Encounters in a postcolonial society. Cambridge: Polity Press.

Lloyd, N., \& Rafferty, A. (2006). Black and minority ethnic families and Sure Start: Findings from local evaluation reports. London: NESS.

Lundberg, O. (2015). Mind the gap: Ethnography about cultural reproduction of difference and disadvantage in urban education. Diss. Göteborg: Göteborgs universitet.

Lunneblad, J. (2013). Den mångkulturella förskolan: Motsägelser och möjligheter [The multicultural preschool: Contradictions and possibilities]. Lund: Studentlitteratur. Retrieved from http://www. qualitative-research.net/index.php/fqs/article/view/447/2890.

McIntosh, P. (1989). White privilege: Unpacking the invisible knapsack. Retrieved from https:// nationalseedproject.org/images/documents/Knapsack_plus_Notes-Peggy_McIntosh.pdf.

Merleau-Ponty, M. (2010). Child psychology and pedagogy: The Sorbonne lectures, 1949-1952. Evanston, Ill.: Northwestern University Press.

Motsieloa, V. (2003). "Det måste vara någonting annat": En studie om barns upplevelser av rasism $i$ vardagen ["There must be something else" An investigation of children's experience of everyday racism]. Stockholm: Rädda barnen. Retrieved from http://resourcecentre.savethechildren.se/sites/ default/files/documents/2605.pdf.

Öhlander, M. (2005). Bruket av kultur: Hur kultur används och görs socialt verksamt. [The use of culture. How culture is used and implemented socially]. Lund: Studentlitteratur.

Runfors, A. (2010). Mångfald, motsägelser och marginaliseringar: En studie av hur invandrarskap formas i skolan [Diversity. Contradictions and marginalization: An investigation of constructions of what it means to be an immigrant in school]. Diss. Stockholm: Nordstedts.

Runfors, A. (2013). Policy, praktik och politik [Policy, pratice and politics]. In P. Björk-Willén, S. Gruber, \& T. Puskás (Eds.), Nationell förskola med mångkulturellt uppdrag (pp. 137-164). Stockholm: Liber.

Schwarz, E. (2011). Bildung und die Perspektive der Person: Ein phänomenologischer Ansatz [Bildung and the perspective of personhood. A phenomenological approach]. In A. Kraus (Ed.), Körperlichkeit in der Schule. Oberhausen: Athena.

Schwarz, E. (2016). Inskolning-Om förnyelse och gemenskap på förskolan [Schooling. On renewal and community at preschool]. In L. Alsterdal \& M. Pröckl (Eds.), Inifrån och Utifrån. Om praktisk kunskap i förskolan. Huddinge: Södertörns Högskola.

Skolverket. (2010). Curriculum for the Preschool Lpfö 98 Revised 2010. Retrieved from https://www. skolverket.se.

Skolverket. (2016). Barn och personal i förskolan hösten 2015 [Children and pedagogues at preschool autumn 2015]. Retrieved from https://www.skolverket.se.

Thomson, P., \& Hall, C. (2008). Dialogues with artists: Analyzing children's self-portraits. In P. Thomson (Ed.), Doing visual research with children and young people (pp. 146-163). London and New York: Routledge.

Ward, C. (2013). Probing identity, integration and adaptation: Big questions, little answers. International Journal of Intercultural Relations, 37, 391-404. https://doi.org/10.1016/j.ijintrel.2013.04.001. 